1. 岸鋶災踣夹態調查

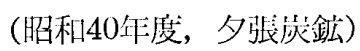

a. 受㩐原因

（1）取扱中の器忉によるるの

$26.4 \%$

（2）落盤に上るもの

$24.9 \%$

b. 受傷部位

（1）手指

$24.7 \%$

（2）胛部水よび軀缺

$19.2 \%$

c. 負傷度 重㑺，柽偒心分類

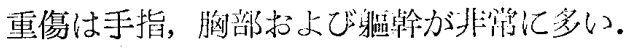

2. 夕拝炭鉱病院見取図の一部紹介

外科外来とX線室および病梀，手術棟との位置似関 係を説明する。

3. 撮影に際しての基本的問題点
a. 患者の安静および苦㑏の琙少
b. 撮影の迅速性と適確性
c. 患者の撮影体位

以上 3 点をできるだけ洬たした上でなおかかつ診断目的 的に合致したX線写真を作る必装がある。

4. 奏技

日常われわれが契際にX線掫影を行なっている垁技お よびX線写真はスライドにより説明する。

\section{5. むすび}

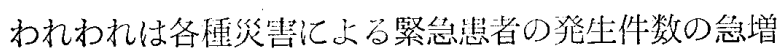

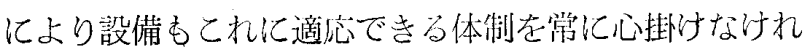

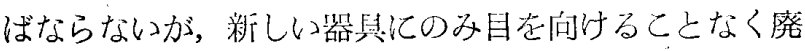
品と思われる器具も創意と工夫に上り新目的に使用する ととが可能である，例えばわれわれが使用した万能撮影 台にしてもわずかの工夫改造により，再生し使用してい る.しかしとのととについてもおのずから限度があり， より合理的に考案された補助具を整供するにこしたとと

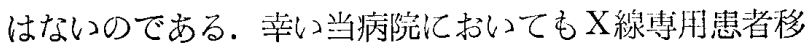
動車を発注済みであるので将来能率的に所期の日的をた っせられるものと思われる。

\section{救急患者の撮影とその取扱いについて}

（特に頭部外傷患者について） 札幌第一病院

表 富司男・ ○渡辺 至人・漶由 仁志

近年交通量の激増とともに，それに比例して交通事故 む一段と増加し, 救急当番を受けむっている当院にも連 日のでとく, 交通外傷患者が運び込まれ, その中でも頭 部外傷患者は，四成，軀翰のそれに肩をならべて意外に 多く，その無渗な姿は見るに陾えないところである。外
第患者が運び込まれた時，まず要求されるのは，X線検 查であるととは，墖を待たないととろであります。

私達は，頭部を主として受けもったのでありますが， 小規模病院として，また，脳外科専門医のいない立場か ら，その撮影法あるいは脳血管撮影にいたるまで，私達 の日常扱っている事柄について㲔告する。

救念の場合のポジショニングなどは，そうでない場合 とは；当然異なってくることであり，鲳者をできるだけ 動かすをとをさけて，X線管と，フィルムとの適当な移 動，专るいは，補眇台を有效に使用するなど，忠者に苦 痛を与えることなく, 早く, し为も最大限沉, 正確な仕 事を進めるととが肝要であります。.

頭部単純撮影については，5〜6方向の撮影を要すると と，また，患者の谷態によってむ撮影の方法は種々と異 なってくるのが, 当然である。

また，引き続き，脳血管撮影に目を向けると，特にそ の補助台については, フィルムの空箱を利用して，良好 な結果をわれわれは得ている。

\section{救急患者の頭部および頚推の撮影について}

北海道立柇棍医科大学付属病院中次 $\mathrm{X}$ 線部

$$
\text { 東 正幸○版東 䈏男 }
$$$$
\text { 川又 清・今野 晋作 }
$$

近来交通機関の発達増加就よび各種鉣工業の拡充等に よって，交通，麾業災害は激増してきています，特に直 接生命に影響を与える頭部および頸推損傷救急患者に対 しての撮影時における取り扱し方の種々な方法や全般的 な注意について，また救牛患者の撮影においては正確な 方法で行なうのはもちろのとと，さらに迅速に行なうと とが要求されます。私其では現在事故現場より病院の診 察室, $\mathrm{X}$ 線線撮影室, 手術場まで, 何等患者に手を触れ るととなく運搬できる方法を開発していまずが，後日発 表させて戴きます。乙れは患者を動かすことなく頭部四 方问撮影，澒推三方向の撮影および頭蓋底の撮影まで行 なえる方式のあのでありなす. 以上の外に現在行なって いる脳血管造影時に使用する各種補助用具を用いて行な っている状沅をスライドによって説明をします。.

\section{頭部外傷患者のX線撮影をめぐって}

札幌医大脳神経外科 講帥

\section{千装 豊昭}

近年交通産業外傷の激增とと屯に，乙れら外傷患者の 死亡原因の約 $70 \%$ が頭部外傷に基づくことが明らかとさ れ, しかもこのうちの約半数は早期かつ適切な治療を行 なうならば救命の可能性あることむ知られ，乙れら救急 医療に関する諸問題はきわめて，重要な課題となってい 